International Journal of Social Sciences and Humanities
Available online at http://sciencescholar.us/journal/index.php/ijssh
Vol. 3 No. 2, August 2019, pages: $95 \sim 104$
e-ISSN: 2550-7001, p-ISSN: 2550-701X
https://doi.org/10.29332/ijssh.v3n2.297

\title{
Information Technology Adoption on Digital Marketing Communication Channel
}

\author{
$\underset{\text { Crosidfor undidere }}{\text { Cross }}$ \\ I Made Sindhu Yoga a , Ni Putu Dyah Permatha Korry ${ }^{\text {b }}$, Ni Made Dhian Rani Yulianti ${ }^{c}$ \\ Article history: Received 27 December 2018, Accepted: 30 April 2019, Published: 10 July 2019
}

\section{Correspondence Author ${ }^{\text {a }}$}

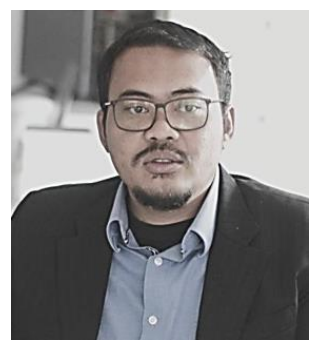

Keywords

communication;

digital marketing;

SMEs;

social media;

ticketing;

\begin{abstract}
This research aimed at contributing academically related to the effort of information technology adoption particularly in digital channels of marketing communication, such as website and social media, to be optimized by SmallMedium size Enterprises (SMEs) in Bali. The main focus is on various travel agents and ticketing in small and medium scale which using the media of information technology in order to build brand awareness of their services and attracting their potential target market. Snowball sampling was used to 16 informants through the semi-structured interview as a qualitative research method. This research aims at addressing how marketers knowing and using information technology to deliver their business activities, while they tend to face a number of barriers to realize and process data from those marketing channels as an analysis supporting tools for crafting marketing campaign strategies and optimizing as a business strategic decision. Furthermore, the paradigm of society that traditional channels and digital channels of marketing communication as a different thing, which lead to the failure of the integration of marketing communication.
\end{abstract}

e-ISSN: 2550-7001, p-ISSN: 2550-701X ๑ Copyright 2019. The Author. SS Journals Published by Universidad Técnica de Manabí. This is an open-access article under the CC BY-SA 4.0 license (https://creativecommons.org/licenses/by-sa/4.0/) All rights reserved.

\section{Contents}

Abstract 95

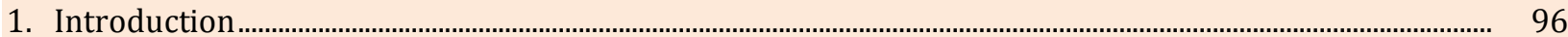

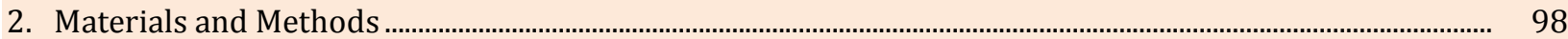

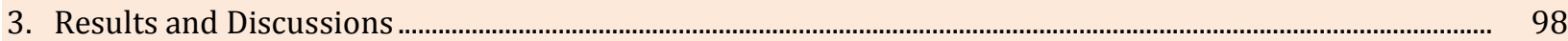

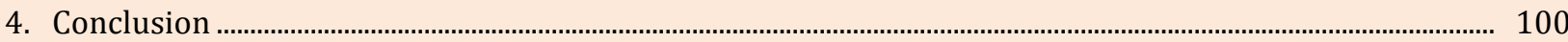

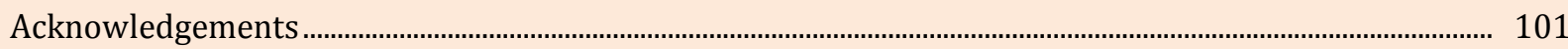

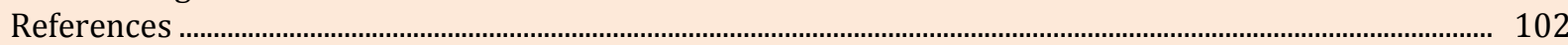

a Universitas Pendidikan Nasional (UNDIKNAS), Denpasar, Indonesia

b Universitas Pendidikan Nasional (UNDIKNAS), Denpasar, Indonesia

c Universitas Pendidikan Nasional (UNDIKNAS), Denpasar, Indonesia 


\section{Introduction}

The growth of developing technology causes big organization or small-medium scale entrepreneurship (UMKM) always need to find a way to advance their competitive position and developing their creativity (Premkumar, 2003). According to this, this small-medium scale enterprise (UMKM) begins to realize a need to create their own profit through investment in information technology as an effort in supporting their needs on infrastructure to provide various updated information and on time (Bhagwat \& Sharma, 2007; Adetunji et al., 2017; Aggarwal, 2017). Unfortunately, instead of increasing exponential users of information technology, several obtained types of research discovered that the level of IT adoption in UMKM still low (MacGregor \& Vrazalic, 2005). Since IT has a big impact on entrepreneurship, there are a lot of researches to examine this. The skill to identify the level of entrepreneurship orientation is the key to the decision maker as a device to adopt digital business. Meanwhile, most of the researches only focused on examining the implementation of the IT system in bigger enterprises (Filis \& Wagner, 2005). The conducted researches in bigger enterprises were about the theory and implementing IT somehow is unsuitable to be applied in the small-medium enterprise (UMKM) (Premkumar, 2003).

Bali as the center of tourism in Indonesia and known for a long time as an international scale is becoming the measurement of the tourism industry with many UMKM related to its every activity. The tourism industry is an industry that involved many people, various activity and as organizations and also companies which provide the product such as holiday service for the consumer. Through the internet, there is a lot of new marketing model which can be used to offer the service to the tourists as potential consumers, then. Thus, the tourism industry has disrupted by dramatic changes through internet development. Internet users tend to do a selection of purchases by online provided service in only one click while comparing among the product service providers on a global scale (Kaur, 2017).

In the tourism industry, the amount of tourists does accommodation reservation, transportation or other tourism products via online is increasing and as if they not reserve it via online, but they will browse the information of tourist destinations via online (Castañeda et al., 2009; Arauz et al., 2016; Dewi et al., 2018). Then, the internet can be considered as a meeting point of tourists with destination operators and able to influence their process of decision making (Jorge et al., 2018). Furthermore, information disclosure through internet media gives chance for UMKM to participate in global competition (Manarte \& Teixeira, 2011). Media in digital marketing communication channel will effectively stimulate tourists to participate in sharing their experiences and can be assumed as an advertising message, then this ad will be positive information for potential consumers as a target market.

\section{Adopting technology in UMKM}

Information technology is very potential to transform UMKM marketing to be bigger, such as customization, the relation between marketing and consumer, new market access, business to business collaboration, new product creation and internal efficiency (Brines et al., 2013). Meanwhile, technology adopting in UMKM is still very limited, it shows that UMKM still has an obstacle to prevent them in utilizing technology for maximum marketing. Adopting information technology in UMKM is an effort to apply supportive devices in information and communication technology such as computer hardware, software, and computer network for internet connectivity (Tan et al., 2009; Ghosh, 2017; Jaminyasa et al., 2017). Adopting technology refers to the stage while technology was chosen to use by a person or organization. In UMKM, tendency to adopt it mostly influence by the owner which often double positioning as a manager in their company, they have an important role in planning and developing the organization. Petroni \& Rizzi (2001), stated that technology adoption based on three stages i.e. cognitive, affective and behavior. In the cognitive stage, the owner realized about technology and analyzing profit and possibility in its used. If they think that technology can help in running the business, so this stage can lead to behavior stage, i.e. taking action and effort in adopting technology in their organization. Furthermore, there are several factors effecting technology 
adoption of UMKM, such as owner characteristics, organization characteristics and extern factor (Petroni \& Rizzi, 2001). These are a description of UMKM triggers to adopt information technology:

1. Owner characteristics and high-level management, emphasize leadership and owner commitment. Commitment refers to the ability of necessary resources and consequence that occurs in the process. Abdullah et al., (2012), emphasized that characteristics of owner leadership can be divided into three to lead the company to adopt technology, such as CEO innovation, CEO behavior toward information technology adoption and knowledge of information technology. Owner characteristics is an important factor which can affect IT adoption in UMKM related to their business scale. UMKM tends to adopt IT when the owner is more innovative, have positive behavior toward adopting IT and shows their interests to know more about knowledge of IT.

2. Organization characteristics is a factor to stimulate the success in the effort of the company to adopt IT as the impact of infrastructure and resources that directly influence the effort in adopting (Abdullah et al., 2012). The strategy to optimize technology, organization structure, culture in using technology and human resources are crucial factors in supporting IT adoption (Khalil, 2002).

3. Extern factor, assumed as one of supporting enterprises to adopt IT. While the company competes in the market, the tendency occurs in the company to adopt technology as a form of creating competitive predominancy (Abdullah, 2012). Extern factors such as competition, social factors, and dependence of other company in using e-commerce media, industry condition, and government police becoming the main stimulant (Grandon \& Pearson, 2004; Udayana, 2017).

Behind intern and extern factors are becoming reasons that triggered UMKM in adopting IT in their business, several previous researchers found that there are indications of unsuccessful UMKM in adopting IT which mostly caused by several things, such as (1) inability of owner or management in translating why and how the company will adopt IT, (2) there is misconception toward adopting process caused by owner or manager that discomprehend about the relation between role of IT toward business operational and unsure about the chance that can be utilized of IT existence, and (3) less capability and ability of company to use and explore the resources in IT as the impact of less knowledge about business IT strategy, limit towards resources such as capital, influence of request by most consumers and also the limit of skills to use IT (Nguyen, 2009; Rinartha et al., 2017).

\section{Digital Marketing Communication Channel}

The existence of internet technology has changed the lifestyle in various aspects, including in way of communication. For a marketer, the internet could be a weapon for creating bound between the consumer and the brand. Furthermore, finally, the marketer also assumes that traditional marketing strategy is getting unable to create sustainability in a business (Kaur, 2017). Then, it makes many marketers transform traditional marketing and structure to be more dynamic. Including the way of communication. Then, marketing communication is developed to be a device for creating long term relation between marketer and potential consumer. Interaction is the main key that should be highlighted via marketing communication through the internet connection (Batinic, 2015). Tourists are often affected by available information on the internet, especially through the comment section or review written by other consumers (Filieri et al., 2015). That comment and review then form the level of trust for potential consumers to choose a tourist destination by reasoning that potential consumer candidate is a more trusting review that written by an experienced tourist who already chose a destination and its tourism product (Abubakar \& Ilkan, 2016). Then this is called as the electronic world of mouth (e-WOM). Furthermore, social media is also useful in the tourism sector since it can be a source for tourism products which is possible as a preference for tourists in choosing and following up the products. Social media also functioned as media for pictures, video and consumer's opinion about their experience during consuming product and service. The usage of social networking by tourist would change the way to browse the information about tourist destination since social media provides information production collaborated service of tourist destination and organization that manage the tourism industry (Zeng \& Gerritsen, 2014). Concept of eWOM and social media are developing to be two things that can be combined and well known as social media word of mouth or s-WOM (Hajli et al., 2014). Moreover, generally, a

Yoga, I. M. S., Korry, N. P. D. P., \& Yulianti, N. M. D. R. (2019). Information technology adoption on digital marketing communication channel. International Journal of Social Sciences and Humanities, 3(2), 95-104. 
company which moves to this industry uses electronic mail (email) also it is also a popular digital marketing communication channel and most used to build communication with consumers. Email makes easier to adjust communication for sending message to potential consumers (Merisavo \& Raulas, 2004). Considering, it needs to be aware that currently, internet browsers are not only interacting among them, but also with the brand as their preference. This phenomenon becomes a chance for the brand in the market to make dialogue directly with the consumers and know them even better (Kaur, 2017).

\section{Materials and Methods}

The used method for this research was done by visiting a travel agent and ticketing located in Denpasar city and Badung Regency. The informants were selected by using a snowball sampling method, i.e. data source sample collecting technique. At first, it was still in little amount, then by the time, it became bigger. It was done since the little amount of data source giving yet satisfying data, then it was necessary to find another informant who can be used as data source (Sugiyono, 2018). Furthermore, through this method, the number of informants as data source was 16 people which is a responsible man in managing digital marketing in a travel agent and ticketing in UMKM scale. That amount than was settled accordingly assumption that obtained information was sufficient. Data were obtained by using semi-structured interview which includes in in-depth interview category, it was a method of the direct interview process. It aimed at finding more open problems. Furthermore, the process of the interview as an effort of data collecting by using guidance such as some questions formed according to theoretically formed indicators, and then explored broadly and intensive based on obtained information from the informants. Data were analyzed by using Miles and Huberman models which describe the analysis from data reduction, presenting data and data verification process. Triangulation of data collecting technique was done in order to measure the credibility of obtained data, it consisted of (1) in-depth interview by using semi-structured questions, (2) documentation and (3) observation in passive participation, i.e. it was limited only for observing and uninvolved in the activity.

\section{Results and Discussions}

This research traced three main things to the subject in tourism industry in travel agent and ticketing field, such as (1) digital marketing communication channel that used, (2) the length used of information technology adoption in business operation, and (3) the stimulated factors or obstacles in effort adopting information technology in their business activity. Informants were the owner or high-level management which were the subject and practitioner in that industry which were already in this field for over five years, so they already comprehend the flow of marketing communication activity that was already built in marketing their service to the consumers. This research was not restraining cluster tourist segmentation that visiting Bali, but it generalized character of overall tourists' segment, since the point of view in this research was the service provider party and not the consumers.

The first focus toward informant was their awareness of various media availability in digital marketing communication channel. Basically, informants knew about variant in digital marketing communication channel, although all of them were not using all of the media, such as the following statement:

Mostly we used email since the guests are from abroad. For the outside Bali, we contact them via email, then we pick them up from the airport, as it.

The informants admitted that email is digital marketing communication that mostly they use. Several informants said that they use some other media, i.e. using social media as promotion media or another facility such as search engine advertising (SEA). Unfortunately, the awareness of optimizing social media or SEA as a marketing communication device to build awareness, interest and bound with the consumer was not in maximum concern, such as the following statement: 
Our social media is Instagram, Facebook, Twitter. So, our marketing itself is more used Google, it used to be Adwords but now already becoming Google Ads, same as Axios for our main marketing. The rest of our social media is only for credibility.

The concern to build awareness in several media in digital marketing communication channel tend to only participate in information technology innovation adopted by other parties in the industry competition. Even though the informants still thought that the user of media in digital marketing communication is needed, even there was implicitly hesitation about optimizing the used and how the obtained data in that media can be used as more than promotion thing.

Actually, if we are talking about effective, it is not that way, social media is equal. Since for the example, media- distance-touring has age specification. So adolescent below 26 years old seldom coming to far abroad. They mostly stay tune via social media. But for the adult, they also use social media, such as Facebook mostly like a digital newspaper. So Instagram and Facebook users are quite different. Since the Facebook users unsure of having Instagram, and in return. So we use both.

The main function of media in digital marketing communication channel that they unknow was Big Data. Statistic data can be withdrawn from digital marketing such as consumer profile and consumer behavior which was indispensable in making marketing strategy which was not known for those six companies. Furthermore, there was a message found that the usage of media caused by recently developed trend. Moreover, in practice, the subject still preferred traditional marketing communication to get and maintain relationships with consumers.

We are seldom using the website since we prefer face to face because nowadays there are so many fraud cases so we are afraid of that. We are face to face except we keep to the agreement with them, they already believe us, they transfer the payment, if the local people we need to meet them first to know maybe they work near that area if we are not using that method, we afraid for the fraud case nowadays.

The act and behavior also were founded as an obstacle in adopting the process of information technology since there were disbelief and perception obstructing that create guilty in digital marketing communication behavior since it had risks such as fraud or consumer trust-lost. Accordance with this, the organization characteristics was a factor that supports or obstruct in adopting the process. Furthermore, organization character in UMKM was also influenced by owner characteristics or high-level management. The majority of informants admitted that if the leader authority such as management or maintenance of marketing content in digital marketing communication tend to get not optimal concern so the media become less effective as a marketing campaign weapon.

It was directly from the boss. The one who edit, open the content and concepts is the boss.

Then, there was an assumption that media in digital marketing communication channel was less important since there was no request for that. According to an informant, in intern factor, there was yet resources specifically for developing digital marketing communication media, meanwhile, from extern factor, opinion such as there was no interest of the consumer to build communication through digital marketing communication media. It became the reason that media was ineffective.

For social media itself, actually we once have created facebook account but there was no one can handle it and also less response from the consumer. I think that it is not worthy of using social media.

The factor of competition with Online Travel Agent (OTA) was giving an image that UMKM in travel agent and ticketing seems to separate apart. It was as the reason for not giving any concern toward the importance of building communication through media in digital marketing communication channel.

Since nowadays technology has been developed, the guests are coming here after finding the information on Google. Commonly, the guest is coming here personally. Competition turns everything down. It also happens in wholesale outside there. The guests mostly using the online system. What is the function of travel back then?

Yoga, I. M. S., Korry, N. P. D. P., \& Yulianti, N. M. D. R. (2019). Information technology adoption on digital marketing communication channel. International Journal of Social Sciences and Humanities, 3(2), 95-104. https://doi.org/10.29332/ijssh.v3n2.297 
For arranging flight ticker, hotel, tour, and transport. But nowadays, since the online system exists, these two are already lost.

For them, tourists market who come personally was the segment which prefers to use OTA service, such as Traveloka. com, Booking.com. Ticket.com and etc. Then, this phenomenon made them feel that their market focus which still needs their service was a tourist that touring in a group. Their targeted business group was business to business (B2B) group that still need their service, and the role of travel agent and ticketing, in which character of this group was sufficient though tradition communication such as exhibition and event and also interaction through email. As the following up of this condition, implicitly was is another reasons obstruct in adopting information technology, less of resources and resistance of owner to focus on information technology usage such as the following statement:

Since the request is reduced, so we cannot optimize the sales and marketing the sell the product. There is no resources and capital. It can be said that the owner does not want to change the strategy since the current strategy has worked from back then.

The other concern was interned thread from the tour guide who became the representative of the company with the guest/tourist. Tourist takeover without involving the company is often done by the guide in their next visit. The tourist tended to feel comfortable and satisfied with the guide service and mostly they will contact the guide directly without confirmation to the company. This was kind of disturbing for the company, so it strengthened the thought that traditional marketing communication was a better way to create bound with the company that builds communication through digital media.

A travel agent has its own cancer cell. Meeting the tourist for the first time will need a tour guide service. They are served, companies with the guide. Then next, the tourist will directly contact the guide. Maybe not everyone like that, but mostly tourist who has repeated will prefer to contact them rather than company again. Before information technology existed the guides still depend on the travel agent, but now? They are free to contact the guide directly. The discourse of ignorant tour guide disciplinary has been an issue for a long time ago, but there is no following up from the government. This makes the chance for the unlicensed tour guide to become a freelance guide.

Regarding those findings, this research can confirm that there were similar findings with previous research about owner role, organization character and extern factor such as competition becoming the factor as a trigger or obstruct the effort of adopting information technology. This was very interesting since there was awareness of UMKM subject about the media in digital marketing communication channel, but because there was no trigger in the organization to realize the function of those media and how to optimize then produce a disinterested attitude in optimizing digital marketing communication channel as an analysis device to produce a strategic decision. Moreover, the other interesting thing was the focus on the comfort of traditional marketing communication media was still believe has the most powerful role in their business sustainability. There were the difference and perception packaging that traditional and digital were different and becoming a thing that then emphasizes lack of understanding that communication integration in business activity was crucial strategy to build bound relation with the consumer.

\section{Conclusion}

The effort of adopting information technology by UMKM in travel agent and ticketing in Bali through using media in digital marketing communication mostly is email, website, and social media. The function of the website and social media is as the source of information about their product and promotion. These two devices are only used as supporting element from their selling technique. Their main devices in communicating are emailed. Reviewing from the type of product and its marketing strategy, email becomes their main communication device. Most of these companies have a partner outside Bali as their main distributor and they serve B2B more than B2C, so it is very reasonable using the website and digital marketing as their supporting device. Moreover, those companies use digital marketing as an excuse for the recent era, digital era. It is unavoidable for them using social media if they do not want to lose in competition. Consumers 
are very happy to browse the information in the virtual world; it is becoming one of the reasons for them using digital marketing.

Using digital marketing in an effective way is not mastered by them and also the features that can support them in their marketing strategy. Cybercrime and other risks of digital marketing also make them un exploring digital marketing deeper. As an example of using social media as communication media with the consumer that often they use is Whatsapp. This application they use is not a business based application but only in a personal way. Another example is in Instagram, some of the companies that use this app even not knowing there are algorithms which need to be concerned to advance account credibility. Even though, they do not use paid to promote to increase the viewer's traffic. It is proof that they un explore digital marketing device they use. The person who manages this digital marketing is not someone that an expert or often the owner itself.

The main function of media in digital marketing communication not they know is Big Data. Statistic data can be withdrawn from the digital markets such as consumer profile and consumer behavior which is indispensable in creating a marketing strategy and it is untouched by those six companies. As an example of a consumer, the profile is to design innovative products according to the users that often accessing social media account, so the products are suitable for market needs. The other example of consumer behavior data in accessing social media such as the time they are actively browsing social media. Those things are very helpful for the company in redesigning market strategy with effective digital marketing.

One interesting finding from the interview is beside their main competitor fellow offline travel agent and online travel agent (OTA), the under covered competitor is the tour guide. They are the first one meeting the guest/tourist at the airport. The tour guide is the person who accompanies guest every day until their last day in a destination so they communicate with the guest verbally and using social media. The satisfying tour guide will be contacted but the guest when they want to repeat their visit to the destination point without informing the travel. This is a big thread by the offline travel agent if they are unable to have a marketing strategy effectively and Big Data can prevent it.

\section{Acknowledgments}

The author would like to thank the editorial boards' team of IJSSH for their valuable time, support and advice in completing the present study.

Yoga, I. M. S., Korry, N. P. D. P., \& Yulianti, N. M. D. R. (2019). Information technology adoption on digital marketing communication channel. International Journal of Social Sciences and Humanities, 3(2), 95-104. 


\section{References}

Abdullah, N. H., Shamsuddin, A., Wahab, E., \& Hamid, N. A. (2012, December). Preliminary qualitative findings on technology adoption of Malaysian SMEs. In 2012 IEEE Colloquium on Humanities, Science and Engineering (CHUSER) (pp. 15-20). IEEE.

Abubakar, A. M., \& Ilkan, M. (2016). Impact of online WOM on destination trust and intention to travel: A medical tourism perspective. Journal of Destination Marketing \& Management, 5(3), 192-201. https://doi.org/10.1016/j.jdmm.2015.12.005

Adetunji, A., Adetunji, A., Adeleke, E., \& Madubuike, S. (2017). Deregulation: the effect of market-led approach to Nigerian universities management. International Journal of Social Sciences and Humanities, 1(1), 1-8. https://doi.org/10.29332/ijssh.v1n1.6

Aggarwal, R. (2017). Different avenues of capital market (secondary market) available for investing in market of yamuna nagar. International Research Journal of Management, IT and Social Sciences, 4(3), 34-50.

Arauz, W. M. S., Gamez, M. R., Perez, A. V., \& Fernandez, M. C. (2016). Microgrids views from a geographic information system. International Research Journal of Engineering, IT \& Scientific Research, 2(11), 57-65.

Batinić, I. (2015). The role and importance of internet marketing in modern hotel industry. Journal of Process Management. New Technologies, 3(3), 34-38.

Bhagwat, R., \& Sharma, M. K. (2007). Performance measurement of supply chain management: A balanced scorecard approach. Computers \& Industrial Engineering, 53(1), $\quad 43-62$. https://doi.org/10.1016/j.cie.2007.04.001

Brines, M., Swartjes, M., Tannemaat, M. R., Dunne, A., Van Velzen, M., Proto, P., ... \& Dahan, A. (2013). Corneal nerve quantification predicts the severity of symptoms in sarcoidosis patients with painful neuropathy. Technology, 1(01), 20-26.

Castaneda, J. A., Frias, D. M., \& Rodriguez, M. A. (2009). Antecedents of internet acceptance and use as an information source by tourists. Online Information Review, 33(3), 548-567. https://doi.org/10.1108/14684520910969952

Cruz-Cunha, M. M., \& Varajão, J. (2011). Innovations in SMEs and Conducting E-Business: Technologies, Trends and.

Dewi, I. G. A. A. O., Dewi, I. G. A. A. P., Kustina, K. T., \& Prena, G. D. (2018). Culture of tri hita karana on ease of use perception and use of accounting information system. International Journal of Social Sciences and Humanities, 2(2), 77-86. https://doi.org/10.29332/ijssh.v2n2.131

Filieri, R., Alguezaui, S., \& McLeay, F. (2015). Why do travelers trust TripAdvisor? Antecedents of trust towards consumer-generated media and its influence on recommendation adoption and word of mouth. Tourism Management, 51, 174-185. https://doi.org/10.1016/j.tourman.2015.05.007

Filis, G. N., \& Spais, G. S. (2007). Stock market reaction on official football club sponsorship announcement using event-study method: The case of Juventus FC and Tottenham Hotspur FC stockholders' behavior. In Proceedings of the 1st Biannual International Conference on Strategic Developments in Services Marketing (by University of the Aegean and University of Glasgow) (Vol. 1).

Ghosh, C. (2017). A study on - evaluating marketing strategies adopted by home appliance for economic development in India. International Journal of Social Sciences and Humanities, 1(1), 9-15. https://doi.org/10.29332/ijssh.v1n1.7

Grandon, E. E., \& Pearson, J. M. (2004). Electronic commerce adoption: an empirical study of small and medium US businesses. Information \& management, 42(1), 197-216. https://doi.org/10.1016/j.im.2003.12.010

Hajli, N., Lin, X., Featherman, M., \& Wang, Y. (2014). Social word of mouth: How trust develops in the market. International Journal of Market Research, 56(5), 673-689. https://doi.org/10.2501\%2FIJMR-2014045

Jaminyasa, I. M., Pulawan, I. M., Martadiani, A. M., \& Amerta, I. M. S. (2017). The marketing mix affect on the consumer buying decision (case study of sausage products at PT. Aroma Denpasar). International Journal of Social Sciences and Humanities, 1(2), 65-74. https://doi.org/10.29332/ijssh.v1n2.44

Jorge, F., Teixeira, M. S., Correia, R. J., Gonçalves, R., Martins, J., \& Bessa, M. (2018, March). A Conceptual Research Model Proposal of Digital Marketing Adoption and Impact on Low Density Tourism Regions. In World Conference on Information Systems and Technologies (pp. 528-537). Springer, Cham. https://doi.org/10.1007/978-3-319-77703-0_52 
Kaur, G. (2017). The importance of digital marketing in the tourism industry. Int. J. Res. Granthaalayah, 5(6).

Khalil, T. M. (2000). Management of technology: The key to competitiveness and wealth creation. McGraw-Hill Science, Engineering \& Mathematics.

MacGregor, R. C., \& Vrazalic, L. (2005). A basic model of electronic commerce adoption barriers: A study of regional small businesses in Sweden and Australia. Journal of small business and enterprise development, 12(4), 510-527. https://doi.org/10.1108/14626000510628199

Merisavo, M., \& Raulas, M. (2004). The impact of e-mail marketing on brand loyalty. Journal of Product \& Brand Management, 13(7), 498-505. https://doi.org/10.1108/10610420410568435

Nguyen, T., Nioi, P., \& Pickett, C. B. (2009). The Nrf2-antioxidant response element signaling pathway and its activation by oxidative stress. Journal of Biological Chemistry, 284(20), 13291-13295.

Petroni, A., \& Rizzi, A. (2001). Antecedents of MRP adoption in small and medium-sized firms. Benchmarking: An International Journal, 8(2), 144-156. https://doi.org/10.1108/14635770110389852

Premkumar, G. (2003). A meta-analysis of research on information technology implementation in small business.Journal of organizational computing and electronic commerce,13(2), 91-121. https://doi.org/10.1207/S15327744JOCE1302_2

Rinartha, K., \& Suryasa, W. (2017, August). Comparative study for better result on query suggestion of article searching with MySQL pattern matching and Jaccard similarity. In 2017 5th International Conference on Cyber and IT Service Management (CITSM) (pp. 1-4). IEEE.

Sugiyono, S., Lastariwati, B., Budiastuti, E., \& Yudianto, A. (2018). Development of authentic assessment instruments for saintifical learning in tourism vocational high schools. Jurnal Pendidikan Teknologi dan Kejuruan, 24(1), 52-61.

Tan, H., Chu, C. R., Payne, K. A., \& Marra, K. G. (2009). Injectable in situ forming biodegradable chitosanhyaluronic acid based hydrogels for cartilage tissue engineering. Biomaterials, 30(13), 2499-2506. https://doi.org/10.1016/j.biomaterials.2008.12.080

Udayana, I. G. B. (2017). Marketing strategies arabica coffee with information technology in Kintamani District Bangli. International Research Journal of Engineering, IT \& Scientific Research, 3(3), 93-102.

Zeng, B., \& Gerritsen, R. (2014). What do we know about social media in tourism? A review. Tourism management perspectives, 10, 27-36. https://doi.org/10.1016/j.tmp.2014.01.001

Yoga, I. M. S., Korry, N. P. D. P., \& Yulianti, N. M. D. R. (2019). Information technology adoption on digital marketing communication channel. International Journal of Social Sciences and Humanities, 3(2), 95-104. 


\section{Biography of Authors}

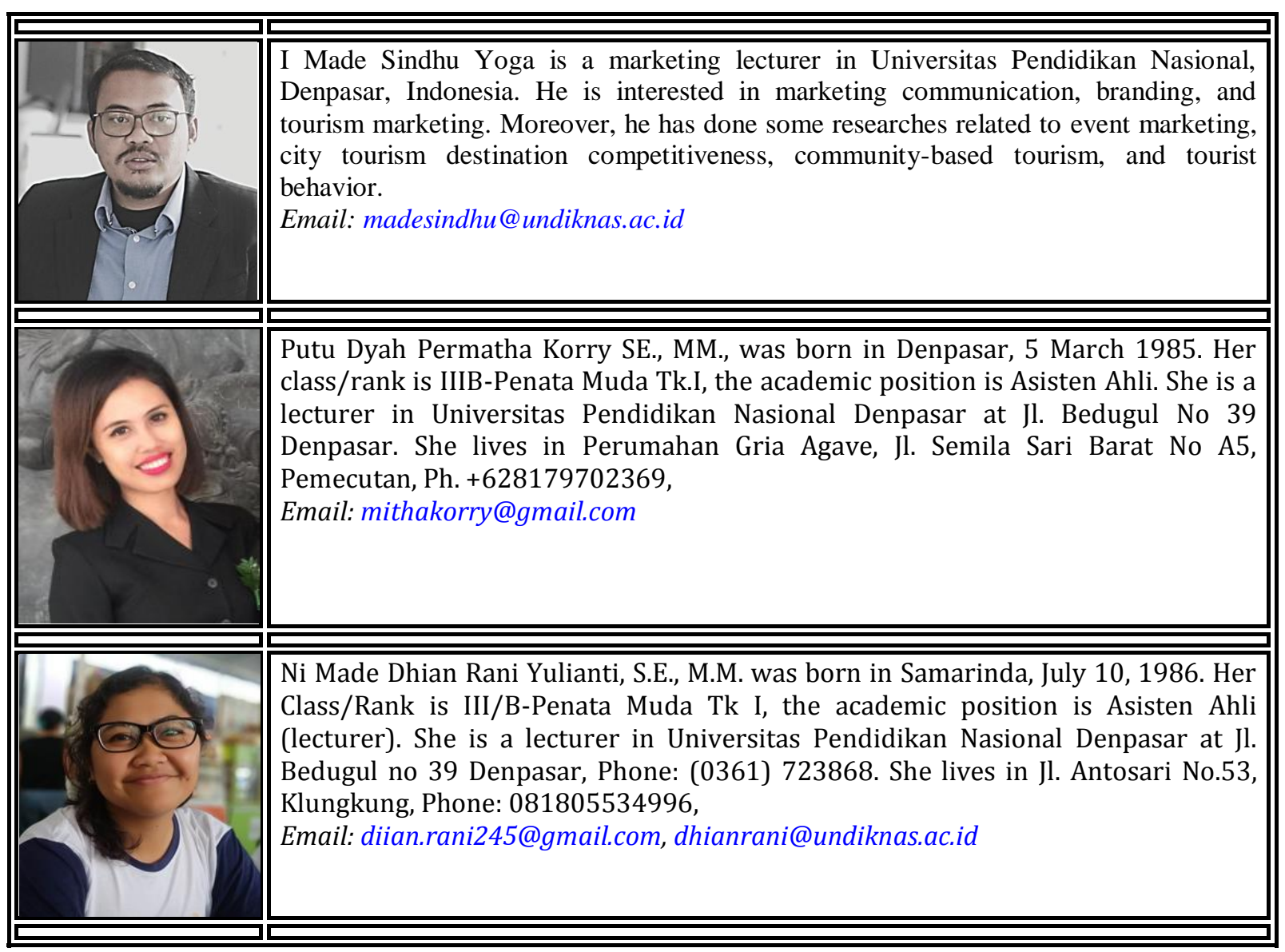

